\title{
MICROHABITAT ECOLOGY OF SEMI-AQUATIC VARANUS FLAVESCENS (REPTILIA: VARANIDAE) IN ALTERED HABITATS
}

\author{
Mijanur K. M. Rahman', Ilgizar I. Rakhimov'1, M. Monirul H. Khan² \\ ${ }^{1}$ Kazan Federal University, Russia \\ e-mail:rahman.bgd@outlook.com,rakhim56@mail.ru \\ 2Jahangirnagar University, Bangladesh \\ e-mail:mmhkhan@hotmail.com
}

Received: 13.10 .2016

\begin{abstract}
A potential microhabitat is very important for the survival and successful reproduction of any wildlife species. In this study we assessed the microhabitat characteristics of Varanus flavescens in the human altered ecosystems of Chalan beel area, Baraigram, Natore by flowing the Visual Encounter Survey method and by using several important material. A semi-aquatic microhabitat of canal and river was preferred by the species as compared to other identified microhabitats. The slow moving water of the river and canal was fresh and somewhat cloudy in character but stagnant water of the pond and beel (floodplain) was semitransparent having lots of phytoplankton and zooplankton. The soil was mostly silty clay. As the study species is cold blooded, the environmental variables like soil, air and water temperatures inside and outside of the microhabitat play major roles for their activity patterns. In order to regulate their body temperature, during a hot sunny day they were more active within the shady area of the microhabitats but at dawn and dusk they were more seen in the sunny areas where temperature was relatively higher. In winter months, the monitor lizards were almost inactive. During that time of the year they live inside the burrow to avoid the extreme cold and foggy weather but during heavy sunshine they come outside of the hole for thermoregulation purpose for a certain time. We noticed that extensive agricultural practice and the excessive use of insecticides may be having a detrimental effect on the microhabitat features important to this semiaquatic lizard. Still the study species is more seen in the human altered ecosystems of Bangladesh. So, to ensure their existence in our close proximity there is an urgent need to create consciousness of the people regarding this beneficial nonvenomous species and their respective microhabitat.
\end{abstract}

Key words: altered ecosystems, Bangladesh, habitat preferences, microhabitat, Varanus flavescens, yellow monitor.

\section{Introduction}

Yellow monitors (Varanus flavescens Gray, 1827) are widely distributed all over Bangladesh (Khan, 2008) and in southern Asia their presence has been reported in the floodplains of Indus, Ganges, and Brahmaputra rivers of Northern India, Bangladesh, Nepal, Myanmar and Pakistan (Auffenberg et al., 1989; Zug et al., 2003; Visser, 2004; Islam, 2009). Nationally the species has been categorized as Near Threatened (NT) on the Red List of Bangladesh Volume 4: Reptiles and Amphibians (IUCN Bangladesh, 2015). Human activities continuously change the unique ecosystems all over Bangladesh, creating altered habitats and inducing reduction, fragmentation and even loss of the pre-existing habitats. Over the last two decades, in most of the regions of Bangladesh local traditional farming has changed into more scientific cultivation practice, aiming at large-scale production. Intensively cultivated fields have rapidly expanded, leading to a drastic reduction and fragmentation of patches of natural and semi-natural vegetation, and to the creation of a more uniform landscape. Intensive agriculture is largely regarded today as one of the major causes of large-scale biodiversity loss. Reptiles are among the taxa that are primarily threatened by land use changes, habitat fragmentation and, particularly, by the expansion of intensive agriculture, worldwide (Heyer et al., 1994; Gibbons et al., 2000). The habitat of the Yellow monitor ( $V$. flavescens) has been described in several studies but no true study has been done yet regarding the microhabitat ecology of this species in the tropical ecosystems of Bangladesh. In addition, $V$. flavescens is a poorly known species (Auffenberg et al., 1989). Studies of usage of microhabitats by any wildlife species are crucial to assess their adaptation to the new environment (Dickinson et al., 2001). Therefore, the objectives of this study was to assess the microhabitat occupation of the Yellow monitor in order to make predictions about what potential conservation tactics can be followed to protect and increase their number in human altered ecosystems.

\section{Material and Methods}

STUDY SITES. The study area is located within the Chalan Beel area of Baraigram, Natore, Bangladesh. It is the largest beel (floodplain habitat) in Bangladesh, which is actually a large inland depression, marshy in character, with a rich floral and faunal di- 
versity. Chalan Beel (2431'12"N, 8900'36"E) currently covers an area of about $26 \mathrm{~km}^{2}$. The area consists of a series of beels connected to one another by various channels to form a continuous water body during the rainy season. The beel area expands into a vast water body with a dense aquatic vegetation as long as the Jamuna River remains flooded during the monsoon months, it dries out in the winter months, leaving only patches of water in the central parts of this zone.

SURVEY OF YELLOW MONITORS. We conducted field survey during October - December 2014 and May - September 2016 in and around the study area. The Visual Encounter Survey method (Heyer et al. 1994) was used for observing the lizards. This method is cost effective and does not disturb the habitats of the target species (Ghimire $\&$ Shah, 2014). Observations of the vegetation and habitat of the lizards were carried out by conducting field trips both on sunny and on rainy days. Everyday field work was done approximately from 6:00 a.m. to $6: 30$ p.m., but sometimes later in the evening. The time of observation and habitat of sighting of each monitor specimen were recorded. For microhabitat study we surveyed almost all types of habitat found in the study area which includes large and small water bodies, slow moving canal and river, homestead forest and agricultural land. Microhabitat characteristics were recorded by collecting data regarding land type, water and soil temperature and type, weather condition, vegetation structure. Temperatures were recorded by using a mercury thermometer and photographs of the vegetation types and lizards were taken by using a NIKON D3200 having a lens of Tamron 70-300 mm.

ETHICAL APPROVAL. All of the data were collected during the study period by the proper approval of Bangladesh forest department. During this study, no animals were harmed or injured intentionally or unintentionally. During this study, we followed all of the code, conduct and legislation for the care and use of animal for scientific purposes.

\section{Results and Discussion \\ MICROHABITAT COMPOSITION AND} CHARACTERISTICS. The vegetation type is one of the key components of the lizard's microhabitat. A total of 127 plant species were identified within the 35 permanent quadrats: trees $(24 \%)$, shrubs (27\%), herbs (33\%), and grasses (16\%) (Table 1).

Although the yellow monitors were found in the same habitat they have different microhabitat preferences and which varies during different parts of the day. Five microhabitats, namely river and canal, beel and pond, dry ground and irrigated area, duff and leaf litter, homestead garden full of different species of trees, shrubs, herbs and grasses near to human habitation were identified as important to this lizard.

The water in both canal and slowly flowing river was clear. Pond and beel water was semitransparent with a high concentration of phytoplankton and zooplankton. The soil was primarily silty clay. Composition and characteristics of five different structural microhabitats of $V$. flavescens are provided in Table 2.

HABITAT PREFERENCES. As yellow monitors are semi-aquatic lizard most of the time they were found in and around aquatic ecosystems. A photograph and habitat of the yellow monitor is shown in Fig. 1. During field study 43 individuals of the yellow monitor were observed in different microhabitats, of which the highest number (37\%) were found in and around the aquatic vegetation of the river and canal and the lowest number (9\%) were seen in irrigated areas (Fig. 2).

Table 1. Vegetation type as a component of microhabitat in the study area

\begin{tabular}{|c|c|c|c|}
\hline $\begin{array}{c}\text { Serial } \\
\text { number }\end{array}$ & $\begin{array}{c}\text { Vegetation } \\
\text { types }\end{array}$ & $\begin{array}{c}\text { Number of } \\
\text { species }\end{array}$ & Proportion $(\%)$ \\
\hline 1 & Trees & 30 & 24 \\
\hline 2 & Shrubs & 35 & 27 \\
\hline 3 & Herbs & 42 & 33 \\
\hline 4 & Grasses & 20 & 16 \\
\hline \multicolumn{2}{|c|}{ Total } & 127 & 100 \\
\hline
\end{tabular}

Table 2. General description and composition of microhabitats found in the study area in which Varanus flavescens occurs

\begin{tabular}{|c|l|l|l|}
\hline Study species & Microhabitat types & \multicolumn{1}{|c|}{ Composition } & Daily activity \\
\hline & Beels and Ponds & $\begin{array}{l}\text { Stagnant water bodies with silty clay soil and dense } \\
\text { aquatic vegetation }\end{array}$ & Whole day \\
\cline { 2 - 5 } & River and canal & $\begin{array}{l}\text { Bank of the river and canal full of dense aquatic } \\
\text { vegetation with clay loam soil and slow moving water }\end{array}$ & $\begin{array}{l}\text { Morning and evening } \\
\text { parts of the day }\end{array}$ \\
\cline { 2 - 5 } Varanus flavescens & Irrigated area & $\begin{array}{l}\text { Paddy field and other agricultural land with different } \\
\text { types of seasonal crops }\end{array}$ & $\begin{array}{l}\text { Morning and evening } \\
\text { parts of the day }\end{array}$ \\
\cline { 2 - 5 } & Duff and leaf litter & $\begin{array}{l}\text { Specially composed of bamboo leaves along with others } \\
\text { decomposed herbaceous plants }\end{array}$ & Midday hours \\
\cline { 2 - 5 } & Homestead garden & $\begin{array}{l}\text { Homestead garden with different undergrowth shrubs, } \\
\text { herbs and grasses near to human habitation }\end{array}$ & Midday hours \\
\hline
\end{tabular}




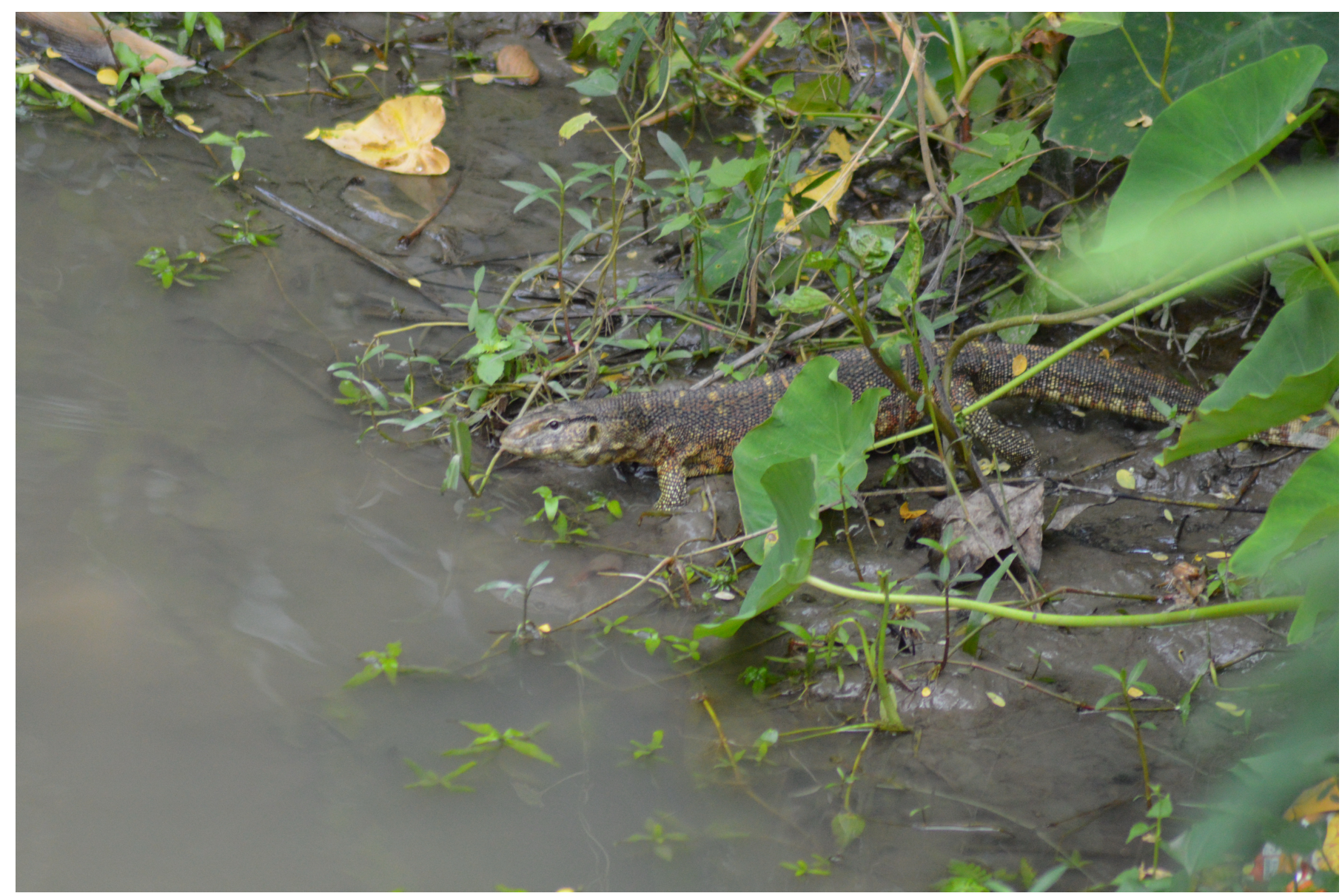

Fig. 1. Yellow monitor (Varanus flavescens) and its habitat found in the village Natabaria, Baraigram, Natore, Bangladesh.

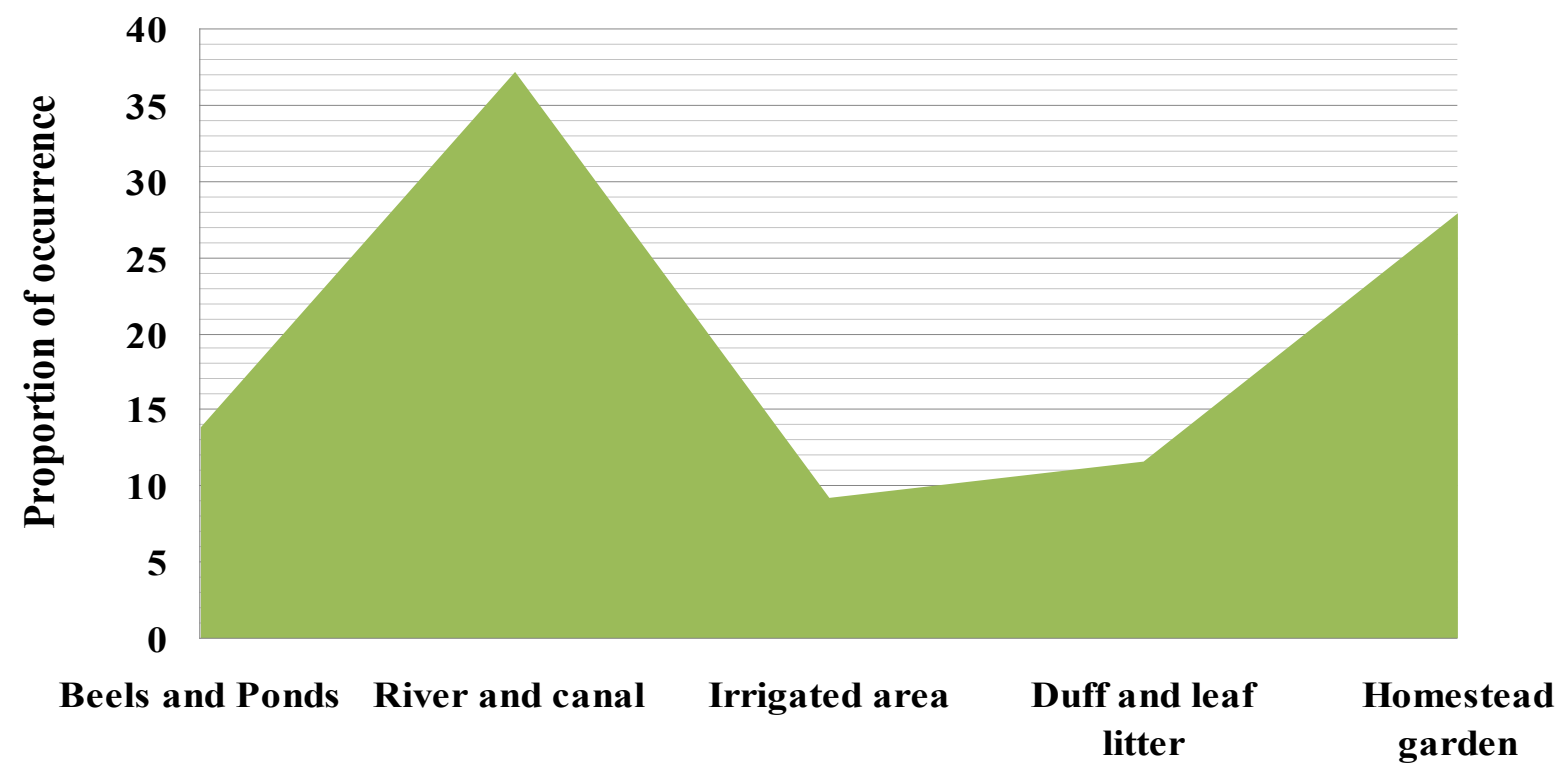

\section{Microhabitat types}

Fig. 2. Microhabitat preferences of Varanus flavescens.

As yellow monitors are cold blooded animal their activities are greatly influenced by environmental variables. During the whole study period the ambient air, water and soil temperatures in shady condition were lower than the-outside sunny condition (Fig. 3, 4). In their respective microhabitat, the study species was more active from 6.30 a.m. to
11.00 a.m. and from 3.00 p.m. to 6.30 p.m. The temperatures in microhabitats occupied by inactive animals out of refuges fluctuated closely with air temperatures. During midday, when the temperature was higher, lizards were more seen in the shady area of the microhabitat. But in the early morning when air, water and soil temperature was relatively 
lower they were more seen in the sunny area of the habitat. During winter months (November and December) their activities were less seen but as the yellow monitors are cold blooded sometimes they had shown basking behaviour in order to do thermoregulation early in the morning.

Every individual of $V$. flavescens needs a suitable microhabitat within their large terrestrial and aquatic ecosystems for survival purposes. In the study area, the micro-environment which is important for the survival of the yellow monitor is created due to the presence of i) agricultural land and homestead gardens consisting of medium tall shrubs with an open canopy, and ii) large and small waterbodies, canals, rivers with a dense aquatic vegetation. So, in terms of microhabitat occupation, $V$. flavescens, found in the ecosystems of Bangladesh, is similar to the species found in Nepal (Ghimire \& Shah, 2014). In a study Karki et al. (2008) mentioned lowland marshes and swamps around water bodies, cultivated lands and floodplains of large rivers as yellow monitor's preferred habitat which is similar to our findings. In another study, Rahman et al. (2015) described a somewhat similar microhabitat for $V$. bengalensis.

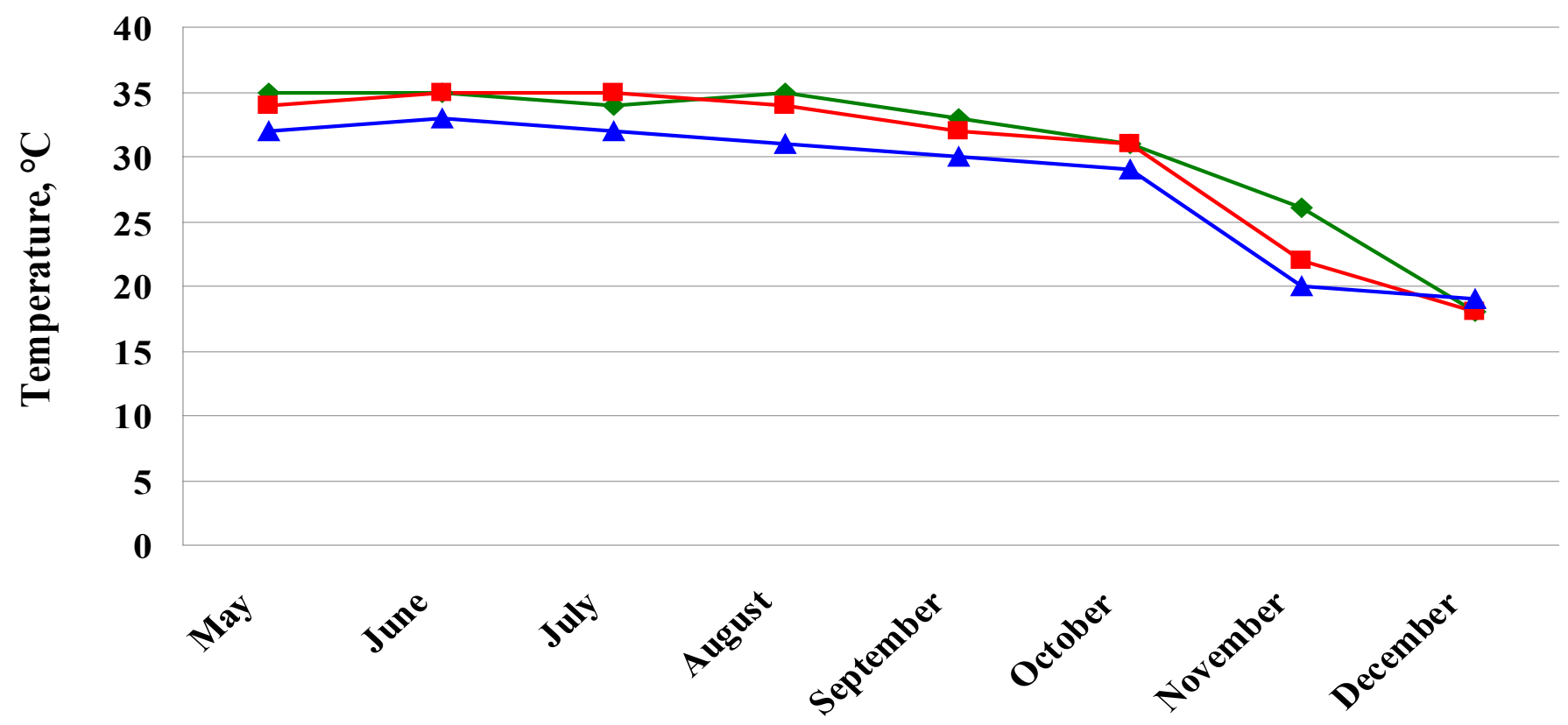

$\neg$ Soil temperature $\rightarrow$ Water temperature $\rightarrow$ Air temperature

Fig. 3. Monthly variation of environmental variables (under sunny conditions).

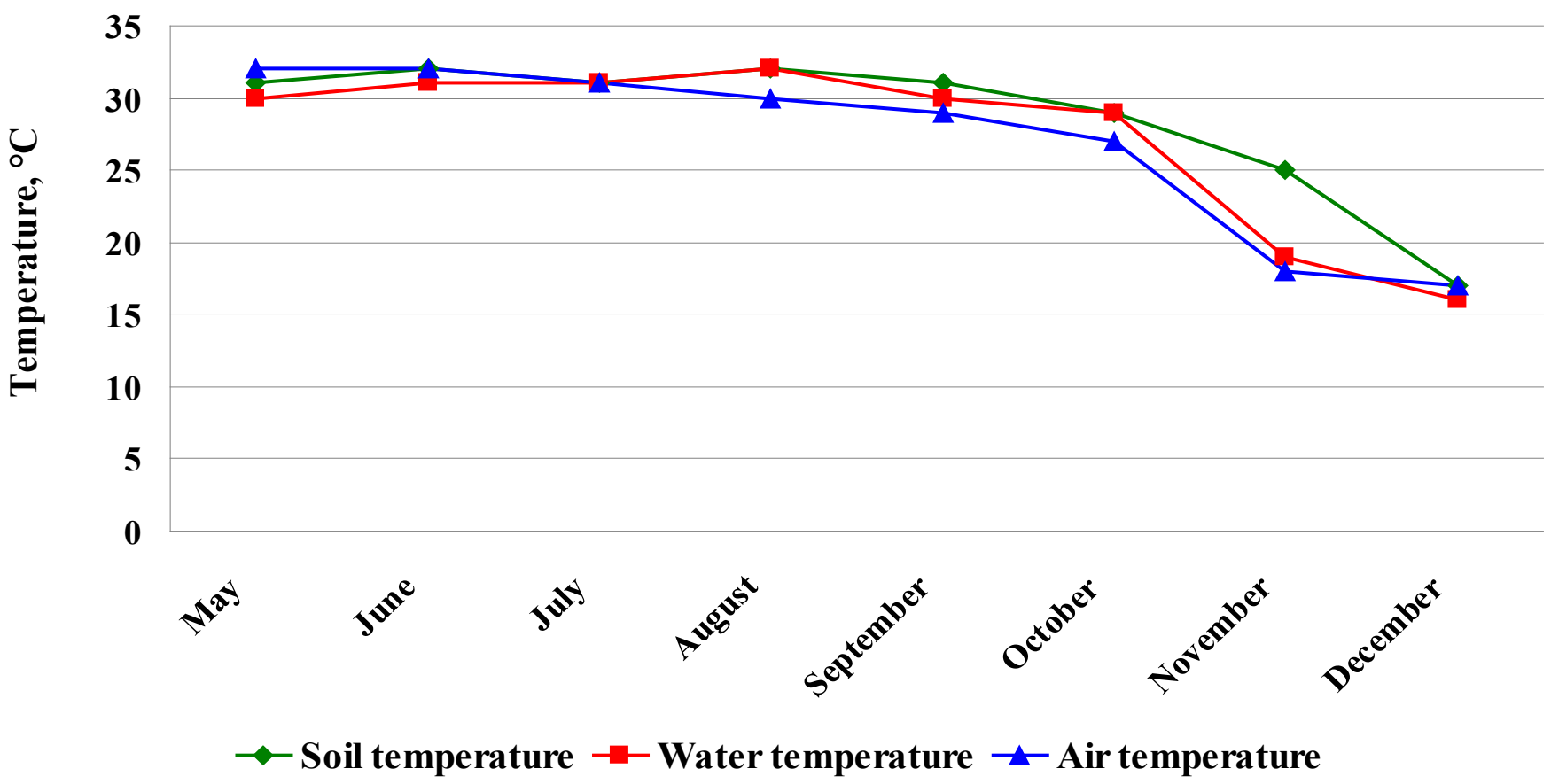

Fig. 4. Monthly variation of environmental variables (under shady condition). 
Like other varanid species $V$. flavescens also shows habitat preferences and they prefer to live in and around aquatic ecosystems; that is why we regard this species as a semiaquatic lizard in this paper. Ali Reza \& Sourav (2010) in natural history notes published by the Herpetological Bulletin mentioned that they also observed this species at the entrance of a burrow close to a seasonally flooded water body. The Australian monitor lizard Varanus mertensi is also a semiaquatic lizard and their microhabitats are similar to that of the yellow monitor (Mayes et. al., 2005).

The yellow monitor's behaviour is greatly influenced by environmental variables. Seasonal variation is also notable in the case of their activities. Other semiaquatic varanids show similar geographic and seasonal variation in activities to terrestrial species (Losos \& Greene, 1988). Ghimire et al. (2014) also mentioned the relationship between yellow monitor's activities and seasonal temperature variations. The present study shows that these animals were more active in the early hours of the day $(6.30-11.00$ a.m. $)$ and in afternoon time $(3.00-6.30$ p.m.). Similar findings were made by Ibrahim (2000) in which was observed that another species of monitor lizard, $V$. griseus of North Sinai, Egypt, is most active between 9.00 a.m. and 10.00 a.m. and least between 7.00 p.m. and 8.00 p.m. Ibrahim (2000) also noted that there is a significant variation in activity level within a 12-hour period.

Yellow lizzards remain almost inactive during the whole winter. Basking behaviour during winter months is a commonly shown activity of $V$. flavescens in order to maintain body temperatures. In a short note Al-Razi et al. (2014) also observed the thermoregulatory behaviour of this species beside a permanent water body. It was lying on a pile of straw ash at the edge of the water. Karki et al. (2008) mentioned that they hibernate in regions with low winter temperatures and low precipitation from November - February where they bask. So, their findings are similar to that of our observations.

\section{Conclusions}

The conservation of microhabitat use by any wildlife species is so important for ensuring their existence in any particular ecosystem. Yellow monitors are more easily seen in the altered habitat than in large forest ecosystems. So, a valuable, effective and sustainable conservation of the yellow monitor is only possible whether conservation of its microhabitats as a whole ecosystem can be realised.

\section{References}

Ali Reza A.H.M., Sourav M.S.H. 2010. Varanus flavescens (Yellow Monitor): distribution and reproduction, Natural history notes. Herpetological Bulletin 112: 38-42.

Auffenberg W., Rahman H., Iffat F., Perveen Z. 1989. A Study of Varanus flavescens. Hardwicke and Gray (Sauria varanidae). Journal of the Bombay Natural History Society 86 (3): 286-307.

Dickinson H.C., John E.F., Lenton S.M. 2001. Microhabitat use by a translocated population of St. Lucia whiptail lizards (Cnemidophorus vanzoi). Animal 4: 143-156.

Ghimire H.R., Phuyal S., Shah K.B. 2014. Protected species outside the protected areas: People's attitude, threats and conservation of the Yellow Monitor (Varanus flavescens) in the Far-Western Lowlands of Nepal. Journal for Nature Conservation 22 (6): 497-503.

Ghimire H.R., Shah K.B. 2014. Status and habitat ecology of the yellow monitor, Varanus flavescens, in the southeastern part of Kanchanpur district, Nepal. Herpetological Conservation and Biology 9 (2): 387-393.

Gibbons J.W., Scott D.E., Ryan T.J., Buhlmann K.A., Tuberville T.D., Metts B.S., Greene J.L., Mills T., Leiden Y., Poppy S., Winn C.T. 2000. The global decline of reptiles, déjà vu amphibians. Bioscience 50: 653-666.

Hayer W.K., Donnelly M.A., McDiamid R.W., Hayekand L.C., Foster M.S. (eds.). 1994. Measuring and Monitoring Biodiversity, standard methods for amphibians. Washington: Smithsonian institution Press. 364 p.

Ibrahim A.A. 2000. A radiotelemetric study of the body temperature of Varanus griseus (Sauria: Varanidae) in Zaranik Protected Area, North Sinai, Egypt. Egyptian Journal of Biology 2: 57-66.

Islam M.A. 2009. Varanus flavescens. In: Encyclopedia of Flora and Fauna of Bangladesh, Amphibians and Reptiles. Dhaka, Bangladesh: Asiatic Society of Bangladesh. Vol. 25. P. 103-104.

IUCN Bangladesh. 2015. Red List of Bangladesh Volume 4: Reptiles and Amphibians. Dhaka, Bangladesh: IUCN, International Union for Conservation of Nature, Bangladesh Country Office. 320 p.

Karki A., Bista R., Humagain S. 2008. Distribution, Behavioral Ecology and Present Status of Varanus flavescens (a literature review paper) in Nepal. The Initiation 2 (1): 49-54.

Khan M.M.H. 2008. Protected Areas of Bangladesh - A Guide to Wildlife. Dhaka, Bangladesh: Nishorgo Program. 290 p.

Losos J.B., Greene H.W. 1988. Ecological and evolutionary implications of diet in monitor lizards. Biological Journal of the Linnean Society 35: 379-407.

Razi H.A., Baki M.A., Alam S.M.I. 2014. Varanus flavescens (yellow monitor): Thermoregulation. The Herpetological Bulletin 129: 27-27.

Rahman K.M.M., Khan M.M.H., Rakhimov I.I. 2016. Microhabitat Use by the Herpetofauna in Mixed-evergreen and Deciduous Forests of Bangladesh. Journal of Pharmaceutical, Biological and Chemical Sciences 7 (1): 841-858.

Mayes P.J., Thompson G.G., Withers P.C. 2005. Diet and Foraging Behavior of the Semi-aquatic Varanus mertensi (Reptilia: Varanidae). Wildlife Research 32: 67-74.

Visser G. 2004. Varanus flavescens. In: E. Pianka, D.R. King (eds.): Varanoid Lizards of the World. Indiana: Indiana University Press. P. 179-183.

Zug G.R., Leviton A.E., Vindum J.V., Wogan G.O.U., Koo M.S. 2004. Checklist of the Myanmar Herpetofauna. Myanmar Herpetological Survey Project. 105 p. 


\title{
ЭКОЛОГИЧЕСКИЕ ОСОБЕННОСТИ ПОЛУВОДНОГО ОБРАЗА ЖИЗНИ ЖЕЛТОГО ВАРАНА VARANUS FLAVESCENS (REPTILIA: VARANIDAE) В ИЗМЕНЕННОЙ СРЕДЕ ОБИТАНИЯ
}

\author{
М. К. М. Рахман ${ }^{1}$, И. И. Рахимов ${ }^{1}$, М. М. Х. Хан ${ }^{2}$ \\ ${ }^{1}$ Казанский федеральный университет, Россия \\ e-mail:rahman.bgd@outlook.com,rakhim56@mail.ru \\ ${ }^{2}$ Джсиханирнагарский университет, Бангладеш \\ e-mail:mmhkhan@hotmail.com
}

\begin{abstract}
Потенциальные микростации обитания очень важны для выживания и успешного размножения любого биологического вида дикой природы. В статье представлены материалы по изучению условий обитания желтого варана в измененных человеком экосистемах в области Ваал Чалан, Барайграм, Натор с использованием методов визуального наблюдения. Изучены условия почвы, температуры воздуха и воды, играющих важную роль в суточной активности варанов. Основные места обитания варанов: полуводные биотопы вдоль каналов и медленно текущих реках. Это отличается от имеющихся представлений о сухопутном образе жизни данного вида. Почва по берегам в основном носит пылевато-глинистый характер. В зимние месяцы, наблюдается значительное снижение активности животных. В это время года они живут в норах, чтобы избежать холода и туманов. Но при теплой погоде они активно выбираются наружу и греются на солнце. Отмечено, что в данном земледельческом районе чрезмерное использование инсектицидов отрицательно влияет на условия обитания варанов. Для обеспечения их существования в условиях измененной среды необходимо изменить отношение людей к этим уникальным объектам живой природы Бангладеш.
\end{abstract}

Ключевые слова: Varanus flavescens, Бангладеш, желтый варан, измененные экосистемы, микростация, приуроченность к местообитаниям. 